\title{
MEDIA VIDEO TUTORIAL UNTUK MENINGKATKAN HASIL BELAJAR PESERTA DIKLAT JARAK JAUH MULTIMEDIA BAGI GURU
}

\author{
Wiwin Sunarsi Tubagus
}

Balai Diklat Keagamaan Manado

wiwin.widyaiswara@gmail.com

DOI : http://doi.org/10.37730/edutrained.v4i2.82

Diterima: 4 September 2020 | Disetujui: 26 November 2020 | Dipublikasikan: 29 November 2020

\begin{abstract}
Abstrak
Penelitian ini bertujuan untuk melihat pengaruh media video pembelajaran dalam meningkatkan hasil belajar peserta Diklat Jarak Jauh Multimedia bagi Guru. Populasi dan sampel pada penelitian ini adalah peserta Diklat Jarak Jauh Multimedia bagi Guru yang berjumlah 40 orang, Metode yang digunakan dalam penelitian ini adalah deskripsi kuantitatif. Dari analisis dan perhitungan yang telah dilakukan, diperoleh dengan tingkat kepercayaan 95\%, ternyata $t_{\text {hitung }}>t_{\text {tabel, }}$ yakni 2,371 $>2,022$. Artinya terdapat perbedaan yang signifikan antara hasil sebelum dan sesudah proses pembelajaran dengan menggunakan media video tutorial pada peserta Diklat Jarak Jauh Multimedia Bagi Guru. Hal ini menunjukkan teknik pembelajaran dengan menggunakan media video efektif, karena dapat meningkatkan kemampuan peserta dalam memperoleh hasil belajar. Para peserta dapat terus menyimak video tutorial yang telah diberikan, sehingga pemahaman peserta terhadap materi yang diberikan semakin meningkat.
\end{abstract}

Kata Kunci: video tutorial, diklat jarak jauh, hasil belajar

\begin{abstract}
This study aims to see the effect of instructional video media in improving the learning outcomes of multimedia distance training participants for teachers. The population and sample in this study were participants of the Multimedia Distance Training for Teachers, 40 participants. The method used in this research is quantitative description. From the analysis and calculations that have been carried out, it is obtained with a confidence level of 95\%, it turns out that tcount $>t$ table, namely 2.371> 2.022. This means that there is a significant difference between the results before and after the learning process using video media for the participants of the Multimedia Distance Training for Teachers. This shows that the learning technique using learning video is effective, because it can improve the ability of participants to obtain learning outcomes. The participants can continue to listen to the video tutorials that have been given, so that the participants' understanding of the material given can increase.
\end{abstract}

Keywords: video, distance learning, learning outcome 


\section{PENDAHULUAN}

Balai Diklat Keagamaan sebagai salah satu institusi yang berperan dalam pengembangan sumber daya manusia di Indonesia, sesungguhnya mempunyai peran penting dalam proses pembelajaran yang akhirnya dapat mencerdaskan kehidupan bangsa.

Sesuai dengan PMA no. 75 Tahun 2015, Balai Diklat Keagamaan Manado menyelenggarakan berbagai jenis Diklat diantaranya adalah Diklat Reguler di Dalam Kampus, Diklat di Wilayah Kerja (DDWK), Diklat di Tempat Kerja (DDTK), Diklat Jarak Jauh (DJJ), dan Diklat Kerjasama (DKS). Peserta yang diundang adalah aparatur Kementerian Agama yang berada di 3 (tiga) Provinsi yaitu Provinsi Sulawesi Utara, Provinsi Sulawesi Tengah, dan Provinsi Gorontalo.

Diklat Multimedia Pembelajaran merupakan salah satu diklat yang diselenggarakan di Balai Diklat Keagamaan Manado. Pelaksanaan Diklat ini menjadi pertimbangan karena sangat dibutuhkan oleh guru untuk meningkatkan kompetensinya tentang ilmu pengetahuan dan teknologi. Sementara pada zaman sekarang dibutuhkan guru yang mampu untuk memasuki tantangan abad 21 yang penuh persaingan global terutama dalam hal pendidikan dan pengajaran.

Diklat Multimedia bagi Guru biasanya dilaksanakan dalam bentuk Diklat Reguler ataupun melalui Diklat di Wilayah Kerja di mana proses pembelajaran dilaksanakan secara klasikal dengan durasi tatap muka hingga 12 jam pelajaran setiap hari. Oleh karena adanya pandemi Coronavirus Desease (Covid 19) yang merebak di Indonesia sejak awal Tahun 2020 maka pelaksanaan Diklat ini dilakukan dengan metode Diklat Jarak Jauh.

Diklat Jarak Jauh dalam bentuk $e$ Learning merupakan solusi kegiatan pembelajaran Diklat pada masa Pandemi Covid 19. Hal ini dikarenakan tuntutan protokol kesehatan pada masa pandemi yang tidak mengizinkan adanya kumpulan orang di satu tempat tertentu, sehingga Diklat reguler hanya dapat dilaksanakan dengan syarat-syarat tertentu dengan mengikuti Pedoman Pelaksanaan Pelatihan Tenaga Teknis Pendidikan dan Keagamaan dalam Tatanan Normal Baru sesuai dengan Surat Edaran Kepala Badan Litbang dan Diklat Kementerian Agama No. 7 Tahun 2020. Pembelajaran yang dilaksanakan secara full online dengan menggunakan aplikasi untuk video conference, chatting group, maupun virtual classroom menuntut pemahaman tentang teknologi yang memadai baik itu untuk panitia pelaksana, widyaiswara, maupun peserta Diklat.

Mengacu pada Pasal 17 Peraturan LAN No. 8 Tahun 2018 tentang Pedoman Penyelenggaraan Pengembangan Kompetensi Pegawai Negeri Sipil melalui e-Learning dimana disebutkan bahwa pembelajaran dalam sehari paling lama 3 Jam Pelajaran (JP) dengan 1 Jam pelajaran adalah selama 45 menit. Dengan demikian maka waktu untuk proses pembelajaran menjadi lebih sedikit. Hal ini menyebabkan peserta kurang waktu untuk memahami materi dan karenanya dapat berpengaruh pada hasil belajar peserta. Perlu adanya metode ataupun media yang tepat untuk dapat meningkatkan hasil belajar peserta didik. Penggunaan media video tutorial sebagai alat bantu widyaiswara mentransfer keilmuan kepada peserta kiranya dapat menjadi solusi untuk hal tersebut.

Berdasarkan latar belakang di atas maka penulis tertarik untuk membahas dan mengkaji berbagai permasalahan tersebut dalam penelitian yang berjudul "Media Video Tutorial Untuk Meningkatkan Hasil Belajar Peserta Diklat Jarak Jauh Multimedia bagi Guru"

\section{KAJIAN PUSTAKA}

\section{Hasil Belajar}

Hasil belajar merupakan bagian terpenting dalam pembelajaran. Nana Sudjana (2009) mendefinisikan hasil belajar siswa pada hakikatnya adalah perubahan tingkah laku sebagai hasil belajar dalam pengertian yang lebih luas 
mencakup bidang kognitif (pengetahuan), afektif (sikap), dan psikomotorik (keterampilan). Dimyati dan Mudjiono (2006) juga menyebutkan hasil belajar merupakan hasil dari suatu interaksi tindak belajar dan tindak mengajar. Dari sisi guru, tindak mengajar diakhiri dengan proses evaluasi hasil belajar. Dari hasil evaluasi tersebut guru dapat mengetahui kelemahan dan kekuatan siswa, sehingga bakat dan minat siswa dapat tersalurkan secara maksimal.

Bloom (Dimyati \& Mudjiono, 2006) menyebutkan enam jenis perilaku ranah kognitif, sebagai berikut:

a. Pengetahuan, mencapai kemampuan ingatan tentang hal yang telah dipelajari dan tersimpan dalam ingatan. Pengetahuan itu berkenaan dengan fakta, peristiwa, pengertian kaidah, teori, prinsip, atau metode.

b. Pemahaman, mencakup kemampuan menangkap arti dan makna tentang hal yang dipelajari.

c. Penerapan, mencakup kemampuan menerapkan metode dan kaidah untuk menghadapi masalah yang nyata dan baru. Misalnya, menggunakan prinsip.

d. Analisis, mencakup kemampuan merinci suatu kesatuan ke dalam bagian- bagian sehingga struktur keseluruhan dapat dipahami dengan baik. Misalnya mengurangi masalah menjadi bagian yang telah kecil.

e. Sintesis, mencakup kemampuan membentuk suatu pola baru. Misalnya kemampuan menyusun suatu program.

f. Evaluasi, mencakup kemampuan membentuk pendapat tentang beberapa hal berdasarkan kriteria tertentu. misalnya, kemampuan menilai hasil ulangan (h. 26-27).

Berdasarkan pengertian hasil belajar di atas, disimpulkan bahwa hasil belajar adalah kemampuan-kemampuan yang dimiliki siswa setelah menerima pengalaman belajarnya. Kemampuankemampuan tersebut mencakup aspek Sikap, Pengetahuan, dan Keterampilan. Hasil belajar dapat dilihat melalui kegiatan evaluasi yang bertujuan untuk mendapatkan data pembuktian yang akan menunjukkan tingkat kemampuan siswa dalam mencapai tujuan pembelajaran.

Hasil belajar sebagai salah satu indikator pencapaian tujuan pembelajaran di kelas tidak terlepas dari faktor-faktor yang mempengaruhi hasil belajar itu sendiri. Sugihartono, dkk. (2007: 76-77), menyebutkan faktorfaktor yang mempengaruhi hasil belajar, sebagai berikut:

a. Faktor internal adalah faktor yang ada dalam diri individu yang sedang belajar. Faktor internal meliputi: faktor jasmaniah dan faktor psikologis.

b. Faktor eksternal adalah faktor yang ada di luar individu. Faktor eksternal meliputi: faktor keluarga, faktor sekolah, dan faktor masyarakat.

\section{Pelatihan Jarak Jauh (PJJ)}

Sesuai dengan PMA no 75 Tahun 2015 tentang Penyelenggaraan Pendidikan dan Pelatihan bagi Pegawai di Lingkungan Kementerian Agama, bahwa untuk mewujudkan Sumber Daya Manusia Kementerian Agama yang berkualitas, professional, berintegritas, dan bertanggungjawab perlu diselenggarakan pendidikan dan pelatihan pegawai.

Pelatihan merupakan bagian penting dalam pembinaan pegawai negeri sipil agar dapat lebih meningkatkan mutu dan produktivitas kerjanya. Berbagai jenis Pelatihan pegawai negeri sipil yang dikembangkan selama ini meliputi Latihan Dasar (pre-service training) dan Pelatihan dalam jabatan (in-service training).

Tujuan pendidikan dan pelatihan menurut Peraturan Pemerintah Nomor 101 tahun 2000 tentang pendidikan dan pelatihan jabatan pegawai negeri sipil:

a. Meningkatkan pengetahuan, keahlian, keterampilan, dan perubahan sikap birokrasi pemerintah

b. Memantapkan birokrasi pemerintah yang makin mampu sebagai pembaharu dan perekat persatuan dan kesatuan bangsa

c. Memantapkan sikap dan semangat pengabdian yang berorientasi pada 
pelayanan, pengayoman dan pemberdayaan masyarakat

d. Menciptakan kesamaan visi dan dinamika pola pikir dalam melaksanakan tugas pemerintah umum dan pembangunan demi terwujudnya kepemerintahan yang baik.

Dari uraian di atas, pelaksanaan pendidikan dan pelatihan bukan hanya pada aspek substansi materi, akan tetapi juga pembinaan sikap disiplin pegawai, serta menciptakan kesamaan visi dan dinamika berpikir sehingga peserta tersebut dapat bekerja sesuai dengan uraian pekerjaannya.

Tujuan pendidikan dan pelatihan yang telah dipaparkan, dapat disimpulkan bahwa tujuan pendidikan dan pelatihan yaitu untuk meningkatkan pengetahuan, kemampuan, sikap dan keterampilan pegawai agar lebih profesional dalam menjalankan pekerjaannya sehingga tujuan organisasi dapat tercapai dan memiliki keterkaitan dengan kinerja pegawai. Sedangkan manfaat pendidikan dan pelatihan yaitu untuk meningkatkan stabilitas pegawai dan dapat memberikan kesempatan bagi pegawai untuk mengembangkan diri agar dalam melaksanakan tugas dapat berjalan dengan efektif dan efisien.

Penyelenggaraan pendidikan dan pelatihan (Diklat) tenaga teknis pendidikan dan keagamaan bagi pegawai di lingkungan Kementerian Agama, sebagaimana diatur dalam Peraturan Menteri Agama Nomor 75 Tahun 2015, menjadi kewenangan Badan Litbang dan Diklat Kementerian Agama yang pelaksanaannya dilakukan oleh Pusdiklat Tenaga Teknis Pendidikan dan Keagamaan bersama Balai Diklat Keagamaan. Pola penyelenggaraan diklat tersebut memiliki keragaman antara lain Diklat di dalam kampus, Diklat di Wilayah Kerja (DDWK), Diklat di Tempat Kerja (DDTK), Diklat Jarak Jauh (DJJ), dan Diklat Kerja Sama (DKS).

Salah satu pola penyelenggaraan diklat yang secara teoretis cukup memiliki peluang untuk mendukung kemudahan akses dan pemerataan kesempatan diklat kepada seluruh pegawai adalah pola Pelatihan Jarak Jauh (PJJ). Pelatihan Jarak Jauh (PJJ) merupakan bentuk diversifikasi diklat yang penyelenggaraannya dilaksanakan secara online (daring). berdasarkan pertimbangan dan tujuan kebutuhan mengembangkan kompetensi teknis substantif Aparatur Sipil Negara (ASN) di wilayah kerja Balai Diklat tanpa harus bertatap muka langsung dengan Widyaiswara sebagai fasilitator. Dengan pola diklat ini dimungkinkan bagi setiap pegawai untuk dapat meningkatkan kompetensinya kapan saja dan dimana saja, tanpa harus meninggalkan tugasnya sehari-hari.

Pendidikan jarak jauh bukan metode baru dalam sistem pendidikan. Metode pembelajaran ini telah digunakan di Amerika Serikat sejak tahun 1892 ketika Universitas Chicago meluncurkan program pembelajaran jarak jauh pertamanya untuk tingkat pendidikan tinggi (fnu.edu, 2019).

Di Indonesia, pembelajaran jarak jauh (distance learning) adalah bagian dari pendidikan jarak jauh (distance education) yang telah diatur dalam undang-undang Republik Indonesia nomor 20 tahun 2003 terkait sistem pendidikan nasional. Pendidikan Jarak Jauh mulai popular di dunia Pendidikan Indonesia sejak merebaknya wabah virus Korona yang masuk ke tanah air sejak awal Tahun 2020. Pembelajaran online merupakan alternatif yang sering dipakai terlebih karena himbauan pemerintah yang melarang kumpulan orang di suatu tempat tertentu. Hal ini menyebabkan begitu banyak institusi Pendidikan yang ditutup secara fisik. Hal ini juga berimbas pada Lembaga kediklatan. Pembelajaran secara klasikal yang biasanya dilakukan melalui Pelatihan Reguler maupun Pelatihan di Wilayah Kerja otomatis belum dapat dilakukan. Dengan demikian alternatif agar proses mendiklat aparatur Kementerian Agama tetap berlangsung adalah dengan menyelenggarakan Diklat Jarak Jauh (DJJ). 


\section{Pelatihan Jarak Jauh Multimedia Pembelajaran}

Pelatihan Jarak Jauh Multimedia Pembelajaran di Balai Diklat Keagamaan Manado dilakukan selama 12 (duabelas) hari dengan durasi tatap muka 3 Jam Pelajaran per hari. Materi yang disajikan terbagi atas 3 (tiga) kelompok yakni: Kelompok Dasar, Kelompok Inti, dan Kelompok Penunjang.

Materi pada Kelompok Inti antara lain adalah:

a. Pemanfaatan Google Classroom sebagai Kelas Maya

b. Desain Formulir Online Google Form

c. Penggunaan Google Site sebagai Web Blog

d. Pemanfaatan Google Drive sebagai Media Penyimpanan Online.

\section{Media Video}

Dalam bahasa latin video diartikan sebagai "Saya lihat (I see)". Setiap format media yang menggunakan sinar katoda untuk menampilkan bagian gambar dari sebuah pesan dapat dikategorikan sebagai video.

Video merupakan serangkaian gambar gerak yang disertai suara yang membentuk suatu kesatuan yang dirangkai menjadi alur, dengan pesanpesan di dalamnya untuk ketercapaian tujuan pembelajaran yang disimpan dengan proses penyimpanan pada media pita atau disk (Arsyad, 2004 dalam Rusman dkk 2011). Video merupakan media audio visual yang menampilkan gerak (Sadiman, 2008).

Jadi disimpulkan video adalah gambar gerak yang terdapat seragkaian alur dan menampilkan pesan dari bagian sebuah gambar untuk tercapainya tujuan pembelajaran.

Video pembelajaran adalah suatu media yang dirancang secara sistematis dengan berpedoman kepada kurikulum yang berlaku dan dalam pengembangannya mengaplikasikan prinsip-prinsip pembelajaran sehingga program tersebut memungkinkan peserta didik mencemarti materi pelajaran secara lebih mudah dan menarik. Secara fisik video pembelajaran merupakan program pembelajaran yang dikemas dalam kaset video dan disajikan dengan menggunakan peralatan VTR atau VCD player serta TV monitor.

Menurut Hooks (2019), Video Pembelajaran dapat dikemas dalam berbagai jenis. Untuk pemanfaatan dalam pembelajaran secara online atau daring, video pembelajaran dapat dibagi menjadi 3 jenis, antara lain:

a. Live Video

Dalam video ini pengajar dapat memberikan penjelasan tentang pembelajaran secara langsung dengan kehadiran fisik si pengajar di dalam video tersebut.

b. Screencast Video

Jenis video ini berupa tutorial dimana pengajar memberikan penjelasan dengan merekam sesuatu dari layar komputer.

c. Animation Video

Pada video jenis ini pengajar dapat mengeksplor kreativitas karena materi yang disajikan dapat dinarasikan dengan karakter animasi.

\section{METODE PENELITIAN}

\section{Metode penelitian}

Metode yang digunakan pada penelitian ini adalah metode deskriptif kuantitatif. Penelitian deskriptif kuantitatif merupakan penelitian yang bertujuan menjelaskan fenomena yang ada dengan menggunakan angka-angka untuk menggambarkan karakteristik individu atau kelompok (Syamsudin \& Damaianti: 2011). Penelitian ini menilai sifat dari kondisi-kondisi yang tampak. Tujuan dalam penelitian ini dibatasi untuk menggambarkan karakteristik sesuatu sebagaimana adanya.

Adapun ciri-ciri penelitian deskriptif kuantitatif sebagai berikut.

1. Cenderung menggunakan satu variabel dalam operasionalnya.

2. Tidak menutup kemungkinan menggunakan dua variabel atau lebih tetapi tidak untuk dihubungkan, dibandingkan, atau dicari sebab-akibat. 
3. Analisis data diarahkan pada pencarian mean, persentase, atau modus.

4. Kegiatan data dimungkinkan untuk diwakilkan.

5. Analisis data dilakukan sesudah semua data terkumpul

Sedangkan Sugiyono (2012: 13) mengemukakan bahwa penelitian deskriptif yaitu penelitian yang dilakukan untuk mengetahui nilai variabel mandiri, baik satu variabel atau lebih (independen) tanpa membuat perbandingan, atau menghubungkan dengan variabel yang lain.

\section{Populasi dan sampel}

Populasi pada penelitian ini adalah peserta Diklat Jarak Jauh Multimedia bagi Guru yang berjumlah 40 orang.

Sampel merupakan bagian dari populasi. Menurut Arikunto (2006) jika populasi di bawah 100 maka semuanya dijadikan sampel. Sehingga sampel pada penelitian ini berjumlah 40 orang.

\section{Teknik pengumpulan data}

1. Observasi dengan menggunakan instrumen observasi yaitu lembar pengamatan, yang terdiri dari lembar pencermatan tes tertulis dan lembar pengamatan untuk mengukur keaktifan dan respon peserta diklat dalam proses pembelajaran.

2. Tes tertulis dengan menggunakan tes pilihan ganda secara online menggunakan google form untuk mengukur kemampuan peserta dalam hal pembelajaran multimedia. Instrumen tes yang dipakai di uji terlebih dahulu tentang validitas dan realibilitasnya. Sebelum dianalisis diuji normalitas dan homogenitas data terlebih dahulu, dan selanjutnya alat pengujian hipotesis menggunakan uji $\mathrm{t}(t$-test $)$.

Hasil penelitian ini berupa data penilaian peserta setelah menggunakan instrumen tes. Instrumen ini terlebih dahulu diuji terlebih dahulu untuk mengetahui validitas dan reliabilitas setiap indikator poin penilaian. Berdasarkan hasil uji validitas dan realibilitas yang telah dilakukan, maka dapat disimpulkan instrumen tersebut valid dan reliabel serta dapat digunakan dalam penelitian.

\section{Teknik analisis data}

Teknik analisis data menggunakan statistik deskriptif. Menurut Sugiyono (2012:148) statistik deskriptif adalah statistik yang digunakan untuk menganalisa data dengan cara mendeskripsikan atau menggambarkan data yang telah terkumpul sebagaimana adanya tanpa bermaksud membuat kesimpulan yang berlaku untuk umum atau generalisasi.

Penelitian akan menggambarkan ketuntasan hasil belajar peserta diklat dengan mendeskripsikan nilai rata-rata, nilai tertinggi, nilai terendah serta nilai yang paling banyak muncul.

\section{HASIL PENELITIAN DAN PEMBAHASAN}

\section{Hasil Penelitian}

Sebelum diberikan materi inti, para peserta Diklat Jarak Jauh Multimedia bagi Guru diharuskan menjawab tes awal untuk mengukur sejauh mana pemahaman peserta tentang multimedia. Tes ini disebut pre test, dan diikuti oleh seluruh peserta Diklat yang berjumlah 40 orang.

Setelah diuji dengan tes awal, para peserta selama 12 hari selanjutnya diberikan materi-materi inti dalam Diklat multimedia dimana pembelajarannya dilakukan dengan metode tatap muka dan diberikan video pembelajaran dari widyaiswara. Video yang diberikan berupa tutorial praktek dimana pembuatannya dilakukan dengan cara screencasting. Hal ini agar peserta saat belajar dapat merasakan suasana yang sama dengan pengajar sehingga dengan demikian pembelajaran akan lebih efektif. Para peserta dibimbing langsung untuk mempraktekkan aplikasi-aplikasi yang ada di dalam materi diklat. Setiap materi inti dibagi 2 sesi, di akhir sesi pertama widyaiswara menugaskan peserta untuk 
menyimak video tutorial yang diakses melalui link youtube, sehingga jika ada peserta yang kesulitan memahami aplikasi yang digunakan saat pembelajaran peserta dapat mengakses video tersebut kapan saja.

Di akhir pelaksanaan diklat, para peserta diharuskan untuk menjawab tes akhir (Pos Test) untuk melihat sejauh mana pemahaman peserta terhadap materi yang telah diberikan widyaiswara/ pemateri. Dari tes tersebut diperoleh nilai terendah yakni skor 45 sebanyak 1 orang, dan skor tertinggi 95 sebanyak 1 orang. Sementara untuk hasil Pos Test diperoleh nilai terendah yakni skor 60 sebanyak 1 orang, dan skor tertinggi 100 sebanyak 8 orang.

Analisis hasil belajar peserta Diklat Multimedia Guru Madrasah di Kementerian Agama Kota Manado dapat diketahui dari data hasil pre test dan pos test. Berdasarkan tabel hasil pre test dan pos test maka dapat dihitung mean atau rata-rata nilai pre test dan pos test dengan menggunakan rumus sebagai berikut:

$$
M x=\frac{f x}{\mathrm{n}} \quad M y=\frac{f y}{\mathrm{n}}
$$

Keterangan:

$\mathrm{Fx}=$ Jumlah nilai Pre test

Fy $=$ Jumlah nilai Pos test

$\mathrm{N}$ = Jumlah siswa

Sehingga didapati bahwa rata-rata pre test $=\frac{2660}{40}=66,5$

Dan rata-rata post test $=\frac{3505}{40}=87,625$

Selanjutnya dihitung selisih rata-rata nilai pre test dan pos test sehingga dapat diketahui progress atau perkembangan nilai hasil belajar peserta sebelum dan setelah mengikuti materi diklat.

$$
\mathrm{M}_{\mathrm{d}}=\mathrm{M}_{\mathrm{y}}-\mathrm{M}_{\mathrm{x}}
$$

$=87,625-66,5$

$=21,125$

Berdasarkan perhitungan di atas, terlihat bahwa nilai rata-rata pos test lebih besar daripada pre test yakni $87,625>66,5$ dengan selisih 21,125. Hal ini menunjukkan adanya kemajuan peningkatan hasil belajar peserta diklat. Selanjutnya dilakukan analisis komparatif dengan teknik uji tberpasangan dimana membandingkan hasil belajar sebelum dan sesudah pembelajaran. Hasil yang di dapat adalah sebagai berikut:

\section{Tabel 1. Hasil Uji t-berpasangan}

\begin{tabular}{l|l}
\hline Uji T-Hitung & $2,37104 \mathrm{E}-12$ \\
\hline T-tabel (taraf kesalahan $=0.05$ dan derajat bebas & 2,02269092 \\
$\mathrm{n}-1$ atau $40-1=39)$ & \\
\hline Syarat: &
\end{tabular}

Jika t-Hitung $>$ T-Tabel maka ada perbedaan pre dan post; Jika T-Hitung < T-tabel maka tidak ada

perbedaan pre dan post

\section{Pembahasan}

Hasil analisis data menunjukkan bahwa pembelajaran sesi 2 setelah peserta menyimak video tutorial dari widyaiswara pada setiap materi inti dapat meningkatkan keaktifan belajar peserta. Hal ini dapat dilihat pada 20 item pertanyaan yang ditunjukan oleh hasil pembelajaran sesi 2 yaitu memiliki nilai sebagai berikut:

Tabel 2. Hasil Keaktifan Peserta

\begin{tabular}{|l|l|l|l|l|}
\hline & $\begin{array}{l}\text { Google } \\
\text { Classroom }\end{array}$ & $\begin{array}{l}\text { Google } \\
\text { Drive }\end{array}$ & $\begin{array}{l}\text { Google } \\
\text { Form }\end{array}$ & $\begin{array}{l}\text { Google } \\
\text { Site }\end{array}$ \\
\hline $\begin{array}{l}\text { Sesi } \\
1\end{array}$ & 71,1 & 69,5 & 71,2 & 72 \\
\hline $\begin{array}{l}\text { Sesi } \\
2\end{array}$ & 84,7 & 86,1 & 81,2 & 82,2 \\
\hline
\end{tabular}

Sehingga jika di rata-ratakan keaktifan pada sesi 2 berjumlah 83,55 . Hal tersebut menunjukkan bahwa penggunaan video tutorial efektif digunakan untuk meningkatkan keaktifan peserta. Hal ini sesuai dengan pendapat Surya (2013) yang menyatakan bahwa adanya prinsip pemacu akan mendorong peserta untuk melakukan berbagai 
tindakan. Pemacu dalam penelitian ini adalah dengan digunakannya video tutorial yang dapat meningkatkan keaktifan peserta yang timbul dari dorongan untuk melakukan tindakan dan untuk melakukan sesuatu sebaik mungkin.

Menurut Slameto (2010) belajar yang efektif dapat membantu siswa untuk meningkatkan kemampuan yang diharapkan sesuai dengan tujuan yang ingin disampaikan. Untuk meningkatkan cara belajar yang efektif perlu memperhatikan beberapa hal berikut: yang pertama kondisi internal, yaitu situasi yang ada di dalam diri siswa itu sendiri. Yang kedua kondisi eksternal, yaitu kondisi yang ada diluar diri pribadi manusia, dan yang ketiga adalah strategi belajar. Belajar yang efisien dapat tercapai apabila dapat menggunakan strategi belajar yang tepat. Strategi belajar diperlukan untuk dapat mencapai hasil yang semaksimal mungkin.

Dalam hal hasil belajar yang diukur dengan pre tes dan pos tes, didapatkan adanya peningkatan nilai. Berdasarkan analisis dan perhitungan yang telah dilakukan, diperoleh dengan tingkat kepercayaan $95 \%$, ternyata $t_{\text {hitung }}>t_{\text {tabel, }}$ yakni $2,371>2,022$. Artinya terdapat perbedaan yang signifikan antara hasil pre tes dan pos tes pada peserta Diklat Jarak Jauh Multimedia bagi Guru. Hal ini sesuai seperti yang dikatakan Daryanto (2013) yang mengatakan bahwa media video dapat meningkatkan hasil belajar karena sifat video yang interaktif dapat membimbing peserta didik untuk memahami suatu materi melalui visualisasi gambar dan suara. Peserta didik dapat secara interaktif mengikuti kegiatan pembelajaran sesuai dengan yang diajarkan dalam video tersebut, sehingga tingkat pemahaman peserta dapat lebih optimal. Hal ini menunjukkan teknik pembelajaran dengan menggunakan media video tutorial efektif, karena dapat meningkatkan kemampuan peserta dalam memperoleh hasil belajar.

\section{PENUTUP}

\section{Simpulan}

Berdasarkan hasil penelitian, maka penulis dapat menarik kesimpulan bahwa Hasil belajar peserta Diklat Jarak Jauh Multimedia bagi Guru mengalami peningkatan yang signifikan. Dari analisis dan perhitungan yang telah dilakukan, diperoleh dengan tingkat kepercayaan $95 \%$, ternyata thitung > ttabel, yakni $2,371>2,022$. Artinya terdapat perbedaan yang signifikan antara hasil pretes dan postes pada peserta Diklat Jarak Jauh Multimedia Bagi Guru. Hal ini menunjukkan teknik pembelajaran dengan menggunakan media video efektif, karena dapat meningkatkan kemampuan peserta dalam memperoleh hasil belajar.

\section{Saran}

Berdasarkan dari hasil kajian tentang urgensi penggunaan media pembelajaran pada kegiatan pendidikan dan pelatihan, maka ada beberapa hal yang perlu peneliti sampaikan, sebagai bahan rekomendasi bagi pihak yang terkait dalam proses belajar-mengajar, antara lain:

a. Pelaksanaan Diklat multimedia perlu dilaksanakan secara berkesinambungan dan berkelanjutan.

b. Untuk meningkatkan pemahaman terkait materi - materi yang telah diajarkan, setelah Diklat para guru dapat terus menyimak video tutorial dari widyaiswara. 


\section{DAFTAR PUSTAKA}

Arief S Sadiman, dkk. (2008). Media pendidikan. Jakarta: PT Raja Grafindo Persada.

Arikunto, S. (2006). Prosedur Penelitian: Suatu Pendekatan Praktik, Edisi Revisi IV. Jakarta: PT Rineka Cipta.

Bungin, B. (2011). Metodologi Penelitian Kuantitatif Edisi 2. Jakarta: Kencana.

Damaianti, S. d. (2011). Metode Penelitian Pendidikan Bahasa. Bandung: Remaja Rosdakarya.

Daryanto. (2013). Media Pembelajaran Peranannya Sangat Penting Dalam. Yogyakarta: Gava Media.

Handayaningrat, S. (2006). Pengantar Studi Ilmu Administrasi dan Manajemen. Jakarta: Gunung Agung.

Kurniawan, A. (2005). Transformasi Pelayanan Publik. Yogyakarta: Penerbit Pembaharuan.

Mudjiono, D. d. (2006). Belajar dan Pembelajaran. Jakarta: PT Rineke. Cipta. Jakarta: PT. Rineka Cipta.

Perkalan no. 8 Tahun 2018. (n.d.). Pedoman Penyelenggaraan Pengembangan Kompetensi Pegawai Negeri Sipil melalui e-Learning .

Permenag No 5 Tahun 2015. (n.d.). Penyelenggaraan Pendidikan dan Pelatihan Pegawai Kementerian Agama.

Pusdiklat Tenaga Teknis Pendidikan dan Keagamaan. (2018). Dokumen II Kurikulum Diklat Teknis Substantif Pendidikan. Jakarta: Pusdiklat Tenaga Teknis Pendidikan dan Keagamaan.

Rusman, d. (2011). Pembelajaran Berbasis Teknologi Informasi dan Komunikasi. Jakarta: Rajawali Press.

Slameto. (2010). Belajar dan faktor-faktor yang Mempengaruhinya. Jakarta: Rineka Cipta.

Sudjana, N. (2009). Penilaian Hasil Proses Belajar Mengajar. Bandung: PT. Remaja Rosdakarya.

Sugihartono. (2007). Psikologi Pendidikan. Yogyakarta. Yogyakarta: UNY Press.

Sugiyono. (2012). SuMetode Penelitian Kuantitatif Kualitatif dan R\&B. Bandung: Alfabeta.

Surur, M. (2016). peningkatkan hasil belajar menggunakan media video pembelajaran pada Kompetensi Dasar Memelihara/Servis Sistem Pendingin Mesin. Jurnal Pendidikan Teknik Mesin, 31 - 36.

Surya, M. (2013). Psikologi Guru Konsep dan Aplikasi dari Guru untuk. Bandung: Alfabeta. 